\title{
Pola Komunikasi Masjid Dalam Menanamkan Nilai Islami Kepada Anak Melalui Program Maghrib Mengaji Perspektif Komunikasi Antar Pribadi (Studi Deskriptif Masjid Kelurahan Harjosari I Kecamatan Medan Amplas)
}

\author{
Bagus Prayugo \\ Program Studi Komunikasi dan Penyiaran Islam (S2) \\ Pascasarjana UIN Sumatera Utara \\ Email: bagusprayugo@gmail.com
}

\begin{abstract}
ABSTRAK
Pola komunikasi merupakan sebuah proses yang dirancang untuk mewakili kenyataan keterpautannya unsur-unsur yang dicakup beserta keberlangsungannya guna memudahkan pemikiran secara sistematis dan logis. Dalam mengenalkan dan menanamkan nilai Islami kepada anak perspektif komunikasi antarpribadi melalui program Maghrib Mengaji menjadi salah satu pondasi utama kepada anak di era globalisasi yang sangat deras terpaannya. Inilah yang menjadi latar belakang penelitian ini dan dapat dirumuskan apa bagaimana pola komunikasi masjid dalam mengenalkan dan menanamkan nilai Islami kepada anak melalui program Maghrib Mengaji perspektif komunikasi antarpribadi. Jenis penelitian ini menggunakan kualitatif deskriptif yaitu mengumpulkan data dan menelaah seluruh data dari berbagai sumber. Dengan menggunakan observasi, dokumentasi dan wawancara kemudian mereduksi data yang sesuai dengan teori dan rumusan masalah serta data disajikan dalam bentuk narasi, dan penarikan kesimpulan. Hasil penelitian yang diperoleh bahwa masjid-masjid daerah Kelurahan Harjosari I kecamatan Medan Amplas melakukan komunikasi pola komunikasi antarpribadi untuk mengenalkan dan menanamkan nilai Islami kepada anak sehingga anak dengan mudah memahami dan menjalankan nilai-nilai Islami yang terdiri dari nilai Aqidah, Ibadah dan Akhlak melalui program Maghrib Mengaji yang dicanangkan oleh pemerintah guna menekan derasnya demoralisasi moral dan agama di era globalisasi yang ditakutkan akan mengancam generasi dimasa yang akan datang. Pengenalan tersebut dilakukan melalui kegiatan rutin seusai Maghrib dengan membaca Al-Quran atau Iqro serta memberikan contoh, pembiasaan dan adanya pemberian penghargaan dan hukuman kepada anak.
\end{abstract}

\section{Kata Kunci: Pola Komunikasi, Nilai Islami, Komunikasi Antarpribadi}

\section{PENDAHULUAN}

Manusia pada hakikatnya adalah manusia sosial, kehidupan manusia akan terus berlangsung jika ada komunikasi yang baik antar sesama manusia. Manusia senantiasa melakukan hubungan dan pengaruh timbal balik dengan manusia yang lain dalam rangka memenuhi kebutuhan dan mempertahankan kehidupannya. Bahkan, manusia akan mempunyai arti jika ada manusia yang lain tempat ia berinteraksi. Komunikasi adalah hubungan timbal balik yang saling mempengaruhi. Ada aksi dan ada reaksi, pelakunya lebih dari satu. Individu dengan individu, 
individu dengan kelompok, kelompok dengan kelompok dan lain sebagainya. Contoh guru mengajar merupakan contoh komunikasi antara individu dengan kelompok. Maka dengan interaksi dan komunikasi merupakan satu kesatuan yang tidak dapat dipisahkan dalam setiap lapisan kehidupan.

Masjid merupakan sebagai tempat sarana beribadah bagi umat muslim, bahkan sejak pada masa Rasulullah Saw masjid bukan hanya sebagai tempat sarana beribadah saja, melainkan sebagai pusat keilmuan, pusat ekonomi, dan berbagai kegiatan lainnya. Di era globalisasi ini kebanyakan masjid sudah terpisah hakikat dan fungsinya sebagai pusat kegiatan umat muslim. Padahal seharusnya di masjid inilah dimunculkan kembali kegiatan-kegiatan yang dapat membangkitkan keilmuan, ekonomi umat, serta kegiatan lainnya. Kontaminasi era globalisasi sudah tidak dapat dibendung, dibutuhkan filter yang kuat untuk menyaring segala bentuk modernisasi dunia, tentu yang kita harapkan kehadiran modernisasi tidak turut menghancurkan atau merusak prinsip kehidupan umat Islam. Semakin derasnya modernisasi yang datang maka akan semakin sulitlah kita untuk menyaring berbagai macam modernisasi yang menerpa jika kita tidak memiliki filter atau saringan yang kokoh. Modernisasi bisa bersifat baik ataupun buruk, tinggal kembali kepada kita sebagai filter sudahkah kita mempunyai saringan yang kokoh untuk menyaring dan memproses itu semua?.

Islam merupakan agama yang rahmatan lil 'alaamiin diturunkan oleh Allah Swt kepada nabi Muhammad Saw dan disampaikan kepada umatnya. Baik buruknya suatu perbuatan jika merujuk kepada Islam adalah Al-Quran dan Sunnah, oleh karenanya kedua pedoman inilah yang harus diikuti oleh setiap muslim sehingga bisa tahu mana yang baik dan mana yang buruk. Karena pada prinsipnya kebenaran berdasarkan wahyu Allah (Al-Quran) adalah mutlak. Oleh sebab itu manusia dituntut untuk mencari kebenaran yang mutlak itu sebagai dasar berkehidupan. Nilai merupakan suatu hakikat yang ingin dicapai oleh setiap manusia. Nilai bisa menjadi suatu keyakinan yang membuat seseorang bertindak atau melakukan berdasarkan pilihannya. Dengan demikian nilai keislaman bisa didefenisikan sebagai konsep keyakinan yang dijunjung oleh manusia mengenai beberapa masalah pokok yang berhubungan dengan Islam untuk dijadikan sebagai pedoman bertingkah laku, baik nilainya bersumber dari Allah Swt maupun hasil interaksi manusia dan tidak bertentangan dengan syariat Islam. Dalam syariat Islam nilai-nilai pokok ajaran Islam itu jika sudah melekat kepada manusia maka manusia tersebut akan memperoleh kebahagiaan yang hakiki. Nilai-nilai pokok ajaran Islam itu adalah nilai Aqidah, nilai Ibadah, dan nilai Akhlaq.

Gerakan Maghrib Mengaji merupakan gerakan Departemen Agama Republik Indonesia yang telah dicanangkan tepat pada hari Sabtu, 14 April 2013 di Jakarta. Gerakan ini dilatarbelakangi oleh jarangnya anak-anak yang mengaji Al-Quran pada sekarang ini, dan dengan harapan dibuatnya gerakan ini adalah bisa memotivasi para orang tua untuk menyuruh anaknya shalat Maghrib dan mengaji di waktu Maghrib. 
Selain itu gerakan ini juga sebagai bentuk mencegah anak-anak dari terpaan moderninasi yang bersifat buruk serta menanamkan pendidikan Islam di tengah masyarakat muslim. ${ }^{1}$

Oleh karenanya, peranan guru Maghrib Mengaji dan juga keluarga sangat penting dalam mendidik dan menanamkan nilai-nilai keislaman kepada anak, diharapkan kegiatan Maghrib Mengaji bisa mengembalikan fungsi masjid sebagai pusat keilmuan dan benteng pertahanan umat dari sifat negatif modernisasi, serta keluarga berperan aktif dalam melaksanakan nilai-nilai keislaman kepada anak untuk mempersiapkan generasi emas yang akan mendatang melalui pendidikan Islam.

\section{TINJAUAN PUSTAKA}

\section{A. Komunikasi Antarpribadi}

Komunikasi antarpribadi merupakan penyampaian pesan dari komunikator ke komunikan atau sekelompok orang dengan berbagai dampak serta memberikan peluang umpan balik kepada komunikan dengan segera. Komunikasi antarpribadi sangat dipentingkan dalam melakukan komunikasi, guna mengatur tata karma dalam pergaulan manusia, karena jika melakukan komunikasi antarpribadi dengan baik maka akan tercipta hubungan yang harmonis serta dapat dengan mudah mengetahui apa yang diinginkan dan tidak diinginkan antara komunikator dan komunikan. ${ }^{2}$

Proses komunikasi pada dasarnya terbagi menjadi kepada dua bagian, yang pertama ada komunikasi secara primer dan yang kedua komunikasi secara sekunder. Komunikasi primer yaitu komunikasi yang terjadi secara langsung tanpa bantuan alat (face to face) bisa menggunakan bahasa, gerakan khusus, isyarat dan sebagainya. Sedangkan komunikasi sekunder yaitu komunikasi yang terjadi secara tidak langsung dengan menggunakan bantuan alat. Proses komunikasi primer identik dengan pola komunikasi tradisional dan komunikasi sekunder identik dengan komunikasi modern. $^{3}$

\section{B. Pola Komunikasi}

Dalam Kamus Besar Bahasa Indonesia (KBBI) pola memiliki makna "bentuk" atau "sistem", cara atau bentuk (struktur) yang tetap, yang mana di dalam pola tersebut dapat dikatakan contoh atau cetakan. ${ }^{4}$ Sedangkan menurut Alex Sobur pola adalah bentuk atau model yang digunakan untuk membuat sebuah objek yang menghasilkan sesuatu dan di dalamnya memiliki unsur-unsur dan pendukungnya. ${ }^{5}$

\footnotetext{
${ }^{1}$ Kementerian Agama Republik Indonesia, Pedoman Gerakan Masyarakat Maghrib Mengaji (GEMMAR MENGAJI), (Jakarta: Direktorat Penerangan Agama Islam DITJEN BIMAS ISLAM), hlm, 4-5.

2 Joseph A. Devito, The Antarpribadi Communication, (New York: Pearson Education Inc, 2009), hlm. 4

${ }^{3}$ Ibid, hlm. 5.

${ }^{4}$ Departemen Pendidikan dan Kebudayaan, Kamus Besar Bahasa Indonesia, (Jakarta: Balai Pustaka, 1996), hlm. 778.

${ }^{5}$ Alex Sobur, Ensiklopedia Komunikasi, (Jakarta: Simbiosa Rekatama, 2006) hlm. 376.
} 
Jadi dapat disimpulkan bahwa pola komunikasi bisa diartikan sebagai gambaran hubungan dua orang atau lebih dalam proses pengiriman dan penerimaan pesan dengan cara yang tepat, sehingga pesan yang dimaksud dapat dengan mudah dimengerti. Di sini akan diuraikan mengenai proses komunikasi secara primer, dan sekunder. 1) Pola Komunikasi Primer yaitu proses penyampaian pesan atau pikiran oleh komunikator kepada komunikan dengan menggunakan lambang sebagai media atau saluran. Dan lambang yang digunakan terbagi kepada dua yaitu lambang verbal dan nonverbal. Lambang verbal yaitu menggunakan bahasa, sedangkan lambang nonverbal menggunakan isyarat, anggota tubuh dan lain sebagainya. ${ }^{6}$ 2) Pola Komunikasi Sekunder yaitu pola komunikasi yang penyampaian pesannya menggunakan alat atau sarana sebagai media kedua setelah memakai lambang sebagai media pertama. Alasan komunikator menggunakan media karena komunikan yang menjadi sasaran jauh jaraknya, maka akan sangat efektif jika komunikasi yang jauh jaraknya digunakan alat untuk bisa menjangkaunya meskipun dalam posisi yang jauh sekalipun yaitu dengan dengan menggunakan teknologi seperti telepon, internet dan lain sebagainya. ${ }^{7}$

\section{Nilai Islam}

Nilai adalah suatu standart penting yang dimiliki oleh setiap manusia, meyakini melalui perspektif hati maka itulah yang disebut dengan nilai. Jika dikaitkan dengan Islam, maka nilai Islam adalah suatu standar keyakinan baik atau buruk yang dianut berdasarkan pedoman yang telah ditetapkan secara mutlak oleh Allah Swt melalui Al-Quran dan Hadist. Nilai-nilai pokok Islam meliputi; 1) Nilai Aqidah yaitu beberapa hal yang wajib diyakini kebenarannya oleh hati, mendatangkan ketenteraman jiwa, menjadi keyakinan yang tidak bercampur sedikitpun dengan keraguan. ${ }^{8}$ 2) Nilai Ibadah yaitu nilai yang mencakup segala perbuatan yang disukai dan diridhai oleh Allah Swt, baik berupa perkataan dan perbuatan serta secara terang-terangan maupun sembunyi-sembunyi dalam rangka mengagungkan Allah Swt dan mengharapak ridha-Nya. Ibadah terbagi kepada dua; Ibadah wajib, seperti sholat, zakat, puasa dan haji. Sedangkan ibadah umum seperti bekerja, makan, minum dan tidur dalam rangka menjaga kesehatan jasmani. 3) Nilai Akhlaq yaitu hal yang berkaitan dengan sifat yang terdapat dalam diri manusia lalu diaplikasikan secara sadar dan terkait dengan perbuatan kepada manusia, alam dan Tuhannya berdasarkan Al-Quran dan hadis.

\section{METODOLOGI}

\footnotetext{
${ }^{6}$ Onong Uchjana Effendy, Ilmu, Teori dan Filsafat, Komunikasi, (Bandung: PT. Citra Aditya Bakti, 2003), hlm. 33.

7 Deddy Mulyana, Ilmu Komunikasi Suatu Pengantar, (Bandung: PT Remaja Rosdakarya, 2010), hlm. 260-261.

${ }^{8}$ Sudamo dkk, Studi Islam, (Surakarta: LPIK UMS, 2011), hlm. 1-2.
} 
Jenis penelitian yang dilakukan adalah penilitian deskriptif kualitatif, yaitu penelitian yang hanya menggambarkan, meringkas, berbagai kondisi dan situasi yang ada. Penulis mencoba menjelaskan kondisi nyata dari objek penelitian dan menghubungkan variable-variabel dan selanjutnya akan dihasilkan deskripsi objek penelitian yang berkaitan dengan pola komunikasi masjid dalam mengenalkan dan menanamkan nilai Islam kepada anak perspektif komunikasi antarpribadi.

Penelitian ini dimaksudkan untuk mengumpulkan informasi mengenai status atau gejala yang ada, yaitu keadaan gejala yang dikumpulkan dilapangan secara nyata adanya. Jadi penulis menggambarkan secara nyata bagaimana situasi dan kondisi yang menjadi fokus penelitian serta apa saja informasi yang dapat diperoleh dilapangan sesuai dengan kenyataan. ${ }^{9}$

\section{HASIL DAN PEMBAHASAN}

\section{Pola Komunikasi Masjid Mengenalkan Islam}

Berdasarkan dari penelitian ini beberapa masjid yang diteliti di kelurahan Harjosari I ditemukan bahwa hampir seluruh masjid masih terdapat program Maghrib Mengaji yaitu dengan datangnya anak-anak yang belajar mengaji sesuai melaksanakan ibadah sholat Maghrib. Bagi anak-anak yang masih belum mengetahui bagaimana bacaan sholat yang harusnya diucapkan, mereka hanya mengikuti gerakan sholatnya saja tanpa membaca bacaan sholat dikarenakan belum mengetahui. Jika dikaji menurut perspektif komunikasi antarpribadi, secara tidak langsung sudah terjadi komunikasi nonverbal antara anak-anak dengan orang dewasa yang sedang sholat berjamaah di masjid.

Anak-anak yang belum mengetahui bacaan sholat di posisikan di barisan shaf paling belakang daerah laki-laki, lalu ketika imam dan Jemaah dewasa lainnya memulai takbir maka secara tidak langsung anak-anak yang belum paham tadi pun mengikuti imam dan Jemaah lainnya. Komunikasi nonverbal yang dilakukan yaitu dengan memberikan isyarat berupa gerakan yang nantinya akan memberikan kemauan anak untuk mengikuti gerakan sholat.

Setelah selesai melaksanakan kegiatan ibadah sholat Maghrib, kemudian anak-anak diajak untuk mengikuti kajian belajar mengaji yang dilaksanakan dihalaman masjid. Disini terdapat hal yang menarik bahwa ada anak-anak yang sudah lancar mengaji dan anak-anak yang belum lancar mengaji akan dibimbing oleh guru mengaji. Sebelum kajian dimulai guru terlebih dahulu menanamkan prinsip Aqidah dengan mengajarkan kalimat "Asyhadu an llaailaaha illallahi, wa asyhadu anna Muhammadan rasuulullah. Rodhitu billahi robba, wa bil Islam diina, wa bi Muhammadin nabiyyan wa rasuula. Robbi zidni 'ilmaa warzuqni fahmaa, wa 'amalan sholihaa." Yang berarti " Aku bersaksi bahwa tiada Tuhan selain Allah, dan Aku bersaksi bahwa nabi Muhammad utusan Allah. Aku ridho Allah Swt sebagai

\footnotetext{
${ }^{9}$ Suharso Arikunto, Manajemen Penelitian, (Jakarta: Rineka Cipta, 2005), hlm. 34.
} 
Tuhanku, dan aku ridho Islam agamaku, dan Muhammad sebagai nabi dan rasul. Ya Allah tambahi ilmuku, berikan aku pemahaman dan juga amal yang baik."

Perspektif komunikasi antarpribadi diatas menggambarkan komunikasi verbal yang dilakukan untuk menanamkan nilai-nilai Islam yang berkaitan dengan Aqidah yaitu keyakinan kepada Allah Swt sebagai Tuhan yang wajib diyakini dan disembah. Sedangkan mengakui ajaran dan kenabian yang disampaikan oleh nabi Muhammad Saw yatiu agama Islam yang hakikat kebenarannya adalah mutlak dari Allah Swt. Prinsip Aqidah inilah yang menjadi tonggak penting dalam sebuah pengenalan dan menanmkan keimanan kepada anak.

\section{Penanaman Nilai Aqidah}

Pengenalan dan pengenalan nilai Aqidah inilah yang menjadi pondasi dasar keyakinan setiap umat Islam. Dengan adanya penanaman nilai Aqidah ini anak akan senantiasa terpatri dalam hatinya bahwa satu-satunya keyakinan untuk takut dan hanya beribadah kepada Allah Swt. Oleh karenanya seorang anak harus tau bahwa salah satu rukun iman yang paling dasar ialah beriman kepada Allah Swt. ${ }^{10}$ Pengenalan nilai Aqidah ini terlihat sejak guru Maghrib Mengaji sebelum memulai belajar mengajar. Apabila dikaji dalam perspektif komunikasi antarpribadi maka komunikasi yang sering kali diulang kemudian menjadi suatu kebiasaan akan menimbulkan respon ingatan yang luar biasa. Tentu jika ini yang terus diajarkan kepada anak, maka anak-anak akan menjadi ingat dan selalu tertancap dalam hatinya untuk meyakini bahwa Aqidah yang benar hanya yakin kepada Allah Swt.

\section{Penanaman Nilai Ibadah}

Setelah anak-anak melafalkan nilai Aqidah tadi lalu sang anak diajarkan untuk membaca Al-Quran ataupun Iqro. Ini bertujuan untuk mendekatkan anak kepada nilai ibadah yang kedua sesudah menanamkan Aqidah maka murid dituntut untuk belajar apa isi ataupun esensi itu dengan cara mempelajari AlQuran. Karena dari Al-Quran inilah nantinya murid-murid akan paham sumber dari ibadah, akhlak, dan baik buruknya suatu perbuatan. Pemahaman nilai ibadah ini yang nantinya akan menjadi pondasi kedua anak agar semakin paham dan apa hakikat manusia sesungguhnya, tidak lain dan tidak bukan untuk beribadah kepada Allah Swt. ${ }^{11}$

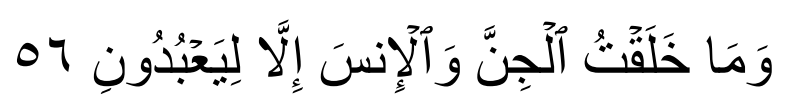

Artinya: Dan aku tidak menciptakan jin dan manusia melainkan supaya mereka mengabdi kepada-Ku. (Q.S Az-Zariyat: 56). ${ }^{12}$

\footnotetext{
${ }^{10}$ Rohmat Mulyana, Mengartikulasikan Pendidikan Nilai, (Bandung: Alvabeta, 2004), hlm. 9

${ }^{11}$ Rahman Ritonga Zainuddin, Fiqh Ibadah, (Jakarta: Gaya Media Pratama, 1997), hlm. 1-5.

12 Departemen Agama Republik Indonesia, Al-Quran dan Terjemahnya, (Semarang: CV Nurcahaya, 1994), hlm. 417.
} 
Setelah selesai mengajarkan Al-Quran selanjutnya guru pun menjelaskan makna-makna yang terdapat dalam Al-Quran. Ini bertujuan untuk lebih menanamkan nilai-nilai yang terkandung dalam Al-Quran kepada anak-anak. Selain itu, penjelasan makna-makna ini memberikan efek penambah ilmu pengetahuan anak tentang nilai-nilai keislaman. Oleh karenanya guru dituntut untuk memiliki wawasan yang luas mengenai nilai-nilai keislaman untuk memberikan pengetahuan kepada anak-anak maghrib mengaji. Jika hal ini sudah dilakukan maka kemungkinan besar anak akan mengerti tentang prinsip-prinsip dasar nilai ibadah yang terus terhubung dengan nilai keyakinan kepada Allah Swt melalui makna-makna Al-Quran. Setelah guru memberikan penjelasan, ketika masuk waktu Isya guru dan murid bersama-sama melaksanakan sholat Isya sebagai bentuk pengaplikasian nilai Aqidah dan nilai Ibadah. Menurut perspektif komunikasi antarpribadi komunikan sudah berhasil untuk mengenal dan menanamkan nilai-nilai keislaman dalam bentuk ibadah sebagai pondasi kedua setelah keyakinan Aqidah kepada Allah Swt.

\section{Penanaman Nilai Akhlak}

Akhlak yaitu yang menjelaskan baik atau buruk, menerangkan apa yang seharusnya dilakukan oleh sebagian manusia kepada sebagian manusia yang lainnya, menyatakan tujuan yang harus dituju oleh manusia dalam perbuatan dan menunjukkan jalan apa yang harus diperbuat. ${ }^{13}$ Akhlak bisa dikategorikan sebagai keadaan jiwa seseorang yang mendorongnya untuk melakukan perbuatanperbuatan tanpa melalui pertimbangan pikiran terlebih dahulu. ${ }^{14}$ Dan ruang lingkup akhlak itu sendiri mencakup dalam berbagai aspek, yaitu akhlak kepada Allah Swt, akhlak kepada makhluk dan akhlak kepada alam.

Metode penanaman akhlak yang dilakukan kepada anak-anak yaitu dengan keteladanan. Keteladanan dalam pendidikan adalah cara yang paling efektif dan dianggap berhasil dalam menerapkan nilai-nilai akhlak kepada anak. Ini dikarenakan pendidik adalah panutan atau idola serta contoh yang baik di mata mereka. Metode ini sangat penting merupakan pondasi dasar yang bisa terwujud dalam bentuk tingkah laku. Oleh karenanya semua bentuk perkataan dan perbuatan pendidik akan terpatri dalam diri anak dan menjadi bagian dari persepsinya. ${ }^{15}$

Cara kedua yaitu "pembiasaan" cara yang dapat dilakukan untuk membiasakan anak didik berfikir, bersikap dan bertindak sesuai dengan ajaran Islam. Pribadi seorang anak dapat dibentuk oleh lingkungannya, oleh karena itu potensi dasar seorang anak harus selalu diarahkan agar tujuan pendidikan dapat

\footnotetext{
${ }^{13}$ Marzuki, Pendidikan Agama Islam, (Yogyakarta: PT Ombak Dua, 2012), hlm. 80-81.

${ }^{14}$ Mansur, Pendidikan Anak Usia Dini dalam Pendidikan, Cetakan Ke-5, (Yogyakarta: PT Pustaka Pelajar Offset, 2014), hlm. 221

${ }^{15}$ Abdul Nashihi Ulwan, Pendidikan Anak dalam Islam, Cetakan ke-1, (Sukoharjo: PT Insan Kamil Solo, 2012), hlm. 516.
} 
tercapai dengan baik yaitu dengan melakukan kebiasaan baik. ${ }^{16}$ Hal ini dapat dilihat ketika anak sudah selesai dalam pelaksanaan Maghrib Mengaji, mereka mencium tangan gurunya dan mengucapkan salam ketika hendak berpisah dengan gurunya.

Kemudian hal yang dapat dilakukan yaitu dengan pemberian "reward and punishmen" (penghargaan dan hukuman). Hal ini dianggap sebagai salah satu valensi nilai-nilai normative yang dapat memberikan efek kepada pendidikan anak. Tentu anak akan merasa senang jika berbuat baik lantas mendapatkan penghargaan. Tetapi sebaliknya jika anak melanggar apa yang telah menjadi ketetapan nilai normatif maka anak akan diberikan hukuman sebagai penyadaran persepsi agar tidak kembali mengulanginya. ${ }^{17}$

\section{KESIMPULAN}

Berdasarkan hasil penelitian tentang pola komunikasi masjid dalam mengenalkan dan menanamkan nilai-nilai Islam kepada anak melaluin program Maghrib Mengaji dapat disimpulkan bahwa pola komunikasi yang dilakukan yaitu dengan menanamkan nilai-nilai ajaran Islam. Nilai-nilai tersebut terbagi kepada tiga bagian yaitu nilai Aqidah, Ibadah dan Akhlak. Penanaman nilai Aqidah dilakukan sebelum melaksanakan kegiatan mengaji yaitu dengan mengucapkan syahadat serta ditambah doa-doa pendek. Tentu ini akan memberikan efek yang dalam ke hati anak mengenai keyakinannya kepada Allah Swt yang berhak untuk disembah.

Selanjutnya penanaman nilai Ibadah yaitu dengan dilakukannya kegiatan membaca Al-Quran atau Iqro sebagai bentuk ibadah kepada Allah dan mengenalkan kepada anak pedoman yang harus diikuti untuk menjalankan syariat Islam haruslah berpoedoman kepada Al-Quran dan Hadist. Ditambah dengan adanya penjelasan mengenai makna-makna yang terkandung dalam Al-Quran disampaikan oleh guru, semakin menambah keyakinan anak untuk menanamkan nilai ibadah. Kemudian metode ketiga dalam mengenalkan anak mengenai nilai akhlak yaitu dengan menjadi suri tauladan yang diberikan oleh guru. Di sini guru harus memberikan contoh yang baik, karena melalui contoh inilah anak akan merespon dalam pikirannya bahwa guru adalah seorang pribadi yang baik. Oleh karenanya setelah guru menjadi contoh yang baik, hendaknya dilakukan usaha selanjutnya "pembiasaan". Ini bertujuan untuk menerapkan nilai-nilai ajaran Islam kepada anak agar senantiasa berlaku baik kepada siapapun. Dan yang terakhir adalah memberikan "reward and punishment" (penghargaan dan hukuman). Ini dilakukan untuk memberika valensi nilai-nilai normatif kepada anak, mana yang harus dilakukan dan mana yang tidak harus dilakukan.

${ }^{16}$ Binti Maunah, Metodologi Pengajaran Agama Islam, Cetakan ke-1, (Yogyakarta: PT Teras, 2009), hlm. 93-94.

${ }^{17}$ Ibid, hlm. 107-108. 


\section{DAFTAR PUSTAKA}

Arikunto, Suharso. 2005. Manajemen Penelitian. Jakarta: Rineka Cipta.

Departemen Agama Republik Indonesia. 1994. Al-Quran dan Terjemahnya. Semarang: CV Nurcahaya.

Departemen Pendidikan dan Kebudayaan, 1996. Kamus Besar Bahasa Indonesia, Jakarta: Balai Pustaka.

Devito, Joseph A. 2009. The Antarpribadi Communication. New York: Pearson Education Inc.

Effendy, Onong Uchjana. 2003. Ilmu, Teori dan Filsafat, Komunikasi. Bandung: PT. Citra Aditya Bakti.

Kementerian Agama Republik Indonesia. 2014. Pedoman Gerakan Masyarakat Maghrib Mengaji (GEMMAR MENGAJI). Jakarta: Direktorat Penerangan Agama Islam DITJEN BIMAS ISLAM.

Mansur. 2014. Pendidikan Anak Usia Dini dalam Pendidikan, Cetakan Ke-5. Yogyakarta: PT Pustaka Pelajar Offset

Marzuki. 2012. Pendidikan Agama Islam. Yogyakarta: PT Ombak Dua.

Maunah, Binti. 2009. Metodologi Pengajaran Agama Islam, Cetakan ke-1. Yogyakarta: PT Teras.

Mulyana, Deddy. 2010. Ilmu Komunikasi Suatu Pengantar. Bandung: PT Remaja Rosdakarya.

Mulyana, Rohmat. 2004. Mengartikulasikan Pendidikan Nilai. Bandung: Alvabeta.

Sobur, Alex. 2006. Ensiklopedia Komunikasi. Jakarta: Simbiosa Rekatama.

Sudamo dkk. 2011. Studi Islam. Surakarta: LPIK UMS.

Ulwan, Abdul Nashihi. 2012. Pendidikan Anak dalam Islam, Cetakan ke-1. Sukoharjo: PT Insan Kamil Solo.

Zainudidin, Rahman Ritonga . 1997. Fiqh Ibadah. Jakarta: Gaya Media Pratama. 